\title{
The Evolution of International Relations Scholarship and its Praxis in Sri Lanka: A Review of Historical Evidence
}

\author{
${ }^{1}$ Nayani Melegoda and ${ }^{2}$ Sandunika Hasangani \\ ${ }^{1}$ Dean, Faculty of Graduate Studies, University of Colombo, Sri Lanka \\ ${ }^{2}$ Research Fellow, Lakshman Kadirgamar Institute, Sri Lanka
}

\begin{abstract}
101 years have passed since the birth of the academic discipline of International Relations (IR) at the University College Wales, Aberystwyth in 1919. After approximately 60 years, the discipline was introduced to the academic realms of Sri Lanka, by appointing Dr. Shelton U. Kodikara as the first professor in IR at the University of Colombo. However, Sri Lanka's praxis of international relations dates back to the pre-colonial times. Arguably, as much historical evidence attests, the praxis of international relations during the early-independence period was materialized in a void of academic expertise. Given this backdrop, the present study reviews the prevailing literature (including primary and secondary historical evidence) on the inception and growth of International Relations as a specific academic discipline of its own identity in Sri Lanka. Below, the authors briefly examine the historical praxis of IR in Sri Lanka, establishment of the discipline in the public university system, including the establishment of the Department of International Relations at the University of Colombo. The status of teaching IR at local universities and the future directions of the discipline receive special attention for the above discussion. The growth of national think tanks focusing on different aspects of the discipline is understood as a positive sign. In addition, the authors also focus on the constructive role played by Ministry of Foreign Relations underpinning the discipline. The study concludes with several suggestions to bridge the gap between the academia and the practitioners of international relations of Sri Lanka.
\end{abstract}

Key words: International Relations (IR), History of IR, IR in Sri Lanka, Praxis of IR, Foreign Policy, University of Colombo. 


\section{Introduction}

In 1918, along with the end of the First World War, and the convocation of the Paris Peace Conference in 1919, Welsh politician and philanthropist David Davies and his sisters founded the world's first chair in International Politics at the University College Wales, Aberystwyth marking the inception of the academic discipline of International Relations (Bain, 2019: p.132). 101 years have passed since the birth of this academic discipline. Named after the American president, the Woodrow Wilson, the chair was established at the University College Wales, with the inaugural task of studying the problems raised by the incipient League of Nations project (Bain, 2019: p.132). During the past century, globalization and technological advancements have greatly contributed to the multidisciplinary nature of the discipline. However, William Bain argues that, despite the noticeable evolution and change of the discipline, "much of contemporary international relations would be intelligible to persons who lived a century ago. International relations is still fundamentally about order and security, power and restraint, and freedom and equality" (Bain, 2019: p.132).

According to Ken Booth (2019), "[t]exts from ancient China, Greece and India, and later from the Middle East and Europe, attest to overlapping concerns with writing what appear as increasingly recognizable 'international' relations". Booth lists down some of the topics that ancient and early modern authors were dealing with, such as war as a necessity, war and ethics, war and politics, power and order, war as irrationality, justice among states, the character of peace, the duty of rules, human nature and conflict, causes of war, nationalism and conflict, states and their interests, military strategies, rights, just war ideals, military power, the value of territory, the meaning and conditions of peace, the balance of power, diplomacy, cooperation and so on. Judging the academic interests of the early modern writes and those of the present, Ken Booth notes that, "[r]eaders will immediately recognize that these primaeval issues remain essential (if not complete) features of a syllabus in any up-to-date IR programme" (Booth, 2019).

Shifting the attention from the international trajectory of IR to the local, this study mainly focuses on the growth and continuity of the academic discipline of IR in Sri Lanka. Below, the authors examine the establishment of the 
academic discipline of IR in the public university system, the growth of national think tanks focusing on different aspects of the discipline, current status of teaching IR at local universities and the historical and contemporary praxis of IR in Sri Lanka. Based on historical evidence the authors first argue that the early praxis of international relations in Sri Lanka (then Ceylon) has materialized in a void of disciplinary experts. 1986 marks the inception of the academic discipline of IR with the appointment of Dr. Shelton U. Kodikara as the first professor in IR at the University of Colombo, approximately 60 years after the establishment of the first chair in International Politics at the University College Wales, at Aberystwyth.

\section{An overview of early praxis of International Relations in Sri Lanka (Ceylon): The presence of the praxis and the absence of experts}

Sri Lanka's diplomatic praxis, and commercial relations can be dated back to the pre-colonial times. The first diplomatic ties were established in the 3rd century BC "between the mighty Indian Emperor Asoka of the Mauryan dynasty and his Sri Lanka contemporary King Devanampiyatissa of Anuradhapura through the medium of the Emperor's two personal emissaries, his son and daughter, Mahinda and Sanghamitta respectively, who brought Buddhism to Sri Lanka" (Mendis,1983: p. ix-xxi). Even before the independence in 1948, Sri Lanka (then Ceylon) established formal diplomatic relations with Australia in 1947. In 1948 following the independence, the Ministry of External Affairs and Defence was formally established, under the direct purview of the Prime Minister of Ceylon. Later in 1977, the ministry was bifurcated, and a separate Ministry for Foreign Affairs was established. The First Foreign Minister of Sri Lanka A. C. S. Hameed (1977-1989) was appointed in 1978 (MFA 2020a).

Sri Lanka established formal diplomatic ties with the following nations during the first ten years of independence: India, France, USA, Turkey, London, Australia, Myanmar, Sweden, Indonesia, Norway, Pakistan, Japan, Italy, Belgium, Germany, Thailand, Israel, China, Nepal, Malaysia, Egypt, Soviet Union, and Canada (MFR, 2020b). In addition, following major landmark international engagements lay the foundation of Sri Lanka's praxis of International Relations (MFR, 2020b; Mendis, 2018). 
November 1947 - Remaining within the British Commonwealth, Ceylon signs three agreements with the British Government on foreign affairs, defence and civil service matters.

July 1948 - Commonwealth Finance Ministers' meeting

January 1950- The Colombo Commonwealth Conference on Foreign Affairs held in January 1950, conceives of "The Colombo Plan" (The Colombo Plan for Cooperative Economic Development in South and Southeast Asia), as a forum to cooperate on socioeconomic development.

July 1951- The Colombo Plan was launched on 1st July 1951.

September 1951 - San Francisco Peace Treaty Conference, which marks Ceylon's historical decision to voluntarily waive the right to reparations from Japan for the damage occurred during World War II.

February 1952 - Colombo Plan Exhibition, demonstrating Ceylon's progress since independence.

1952 - China - Ceylon Rice Rubber Pact

October 1953 - Visit of the Vice President, Richard Nixon April 1954 - Visit of Queen Elizabeth II.

April 1954- The Colombo Powers conference hosted by Ceylon in Kandy from 28 April to 2 May 1954, with Southeast Asian Prime Ministers.

April 1955- In April 1955, Sri Lanka (then Ceylon) met with 29 countries from Africa and Asia, in Bandung, Indonesia to discuss Afro-Asian solidarity and laid foundation for the Non-Aligned Movement (NAM).

December 1955- Sri Lanka, then Ceylon, obtained membership of the United Nations on 14 December 1955, along with nine other countries.

1956- Prime Minister, S. W. R. D. Bandaranaike was the first Head of Government of Sri Lanka to address the United Nations General Assembly. ${ }^{1}$

\footnotetext{
${ }^{1}$ The list has been compiled based on MFR, 2020b and Mendis, 2018.
} 
However, despite the presence of the continuous, yet arguably challenging path of praxis, many scholars have noted the absence of International Relations scholars and institutes in the early post-independence of Sri Lanka. As Sir Ivor Jennings notes in 1954, Sri Lanka's (then Ceylon's) “main source of information about foreign affairs is the Foreign Office, whose material is circulated by the Commonwealth Relations Office. It is the only independent country in the Commonwealth which has no Institute of International Affairs" (Jennings, 1954: p.343). Jennings is critical of the disintegrated and theoretically contradictory foreign policy practice at his time and emphasizes the absence of experts on international affairs: "By economic interests and cultural affiliation...Ceylon belongs to the western bloc. It dislikes 'imperialism' or 'colonialism' and therefore will not support the French in Indo-China. It does not want to be involved in an East-West war, and it is easily persuaded ... that neutralism is a feasible policy. The greatest danger ...is ignorance. ...Even so, it is not unfair to say that Ceylon has not a single expert on international affairs. It would take a whole generation to create that elite of instructed opinion which is so influential in the policies of other countries" (Jennings, 1954: p. 346).

Similarly, in 1960, Wriggins notes in his Ceylon: Dilemmas of a New Nation, the notable absence of a formal and a scholarly foreign policy discourse in the country. "Apart from a few individuals in the democratic parties, articulate Marxists, and a handful of journalists, few seriously debated foreign policy alternatives. There appeared to be a notable unconcern with foreign affairs for a people so much affected by developments abroad" (Wriggins, 1960: p.415).

What both Jennings and Wriggins note is the absence of a 'scientific community' and 'an institute' within Sri Lanka (Ceylon) in researching, theorizing, and recording political, commercial and other formal and informal diplomatic praxis of the island. This is in the backdrop of an established scholarly tradition in International Relations in the world, marked with the inception of The Department of International Politics, the first of its kind in the world, in the University of Wales (now Aberystwyth University) in 1919.

More recently in 1984, H.S. S. Nissanka, in his Sri Lanka's Foreign Policy: A Study of Non - Alignment (Nissanka, 1984: p. iii) states that "the foreign 
affairs of Sri Lanka (Ceylon) during the recent past seemed to have been a field outside the scope of research by scholars. This was largely due to the lack of research facilities. Valuable documents relating to the foreign policy of Sri Lanka are kept in dusty files untouched by human hands even though twenty-five years have lapsed since the events occurred. So far there is no department of International Relations at any of the seventeen universities of Sri Lanka. These two factors - the non-cooperation by the Ministry of External Affairs and the absence of academic interest in the field of foreign affairs have brought about a state of inertia of which I too was a victim." Nissanka's criticism is strong, and imperative on two fronts. First, the country has not prioritized establishing an academic field or a scientific community of International Relations. Secondly, there is an absence of cooperation between the Ministry of External Affairs, those who represent the praxis, and the academic communities, those who could contribute to formalize and standardize the praxis.

\section{International Relations in the public university system in Sri Lanka}

In the above backdrop, below the authors locate the emergence and establishment of International Relations as a distinct academic discipline in the modern higher education and the university system in Sri Lanka. The legacy of Professor Shelton U. Kodikara, the island's first professor in International Relations, and the establishment of the Department of International Relations in the Faculty of Arts, University of Colombo are two watersheds discussed below. In addition to that the authors also examine the prevailing trends in contemporary IR teaching in the country.

The beginning of modern higher education in Ceylon was in 1870 when the Ceylon Medical School was established followed by Colombo Law College (1874), School of Agriculture (1884) and the Government Technical College (1893) (Jayasundara, 2014). The origins of the modern university system in Sri Lanka dates back to 1921 when the Ceylon University College was established admitting students as a part of the University of London's overseas academic network (Kaligalagedara and Kaushalya, 2017). The University of Ceylon was established in 1942 by the Ceylon University Ordinance No.20 of 1942, which was to be unitary, residential, and autonomous. The University of Ceylon remained as the only institution of a 
University rank until 1958. The University was to be located at Peradeniya as a residential University (Kaligalagedara and Kaushalya, 2017).

Sir Ivor Jennings was appointed Principal of the Ceylon University College in 1940 and became the first Vice Chancellor of the University of Peradeniya, where he served continuously from 1942 to 1955. After returning to England, he became the Vice Chancellor of the University of Cambridge from 1961 to 1963 (Scott, 2006). University of Ceylon became the University of Sri Lanka following the University of Ceylon Act No. 1 of 1972 resulting in a more centralized administration and more direct government control. Universities Act No. 16 of 1978 resulted in creation of six more universities (Kaligalagedara and Kaushalya, 2017).

As quoted by Jayawardane in a paper titled "Security Studies in Sri Lanka: A Late Development" (2001) Professor Frank Thistlethwaite, Vice Chancellor, University of East Anglia, who was invited to advise the National Council of Higher Education (NCHE) on the creation of the Colombo Campus as a separate University made an interesting observation in his final report in 1967: "Colombo [University] should capitalize its position as the university in the heart of the country's metropolis. It should draw strength from and contribute to the characteristic activities of the capital city: government and administration, diplomacy and international relations, law, finance, trade and commerce and communications" (Thistlethwaite, 1967: p.4, emphasis added).

\subsection{The legacy of Professor Shelton U. Kodikara}

The emergence and establishment of International Relations as a distinct academic field in Sri Lanka can be traced along the legacy of Dr. Shelton U. Kodikara and later with several other scholars at the University of Colombo. Dr. Kodikara returned to Sri Lanka having completed his MA in International Relations at University of Denver, USA in 1958 and Ph.D in International Relations at the London School of Economics in 1962. The title of his doctoral dissertation was Indo-Ceylon Relations since Independence and it was later published as a book by Ceylon Institute of World Affairs in 1965. His analysis of Indo-Ceylon relations has been known as a "pioneer venture in this field" (Phadnis, 1967) where he provides historical, cultural, economic, strategic, and political perspectives of Indo-Ceylonese relations 
in the context of social pressures and internal dynamics of both the countries (Phadnis, 1967).

Kodikara observes that the Ministry of External Affairs, Sri Lanka had not developed a strong research interest in foreign policy. "Although a Policy planning division has existed for some time in the Ministry, it is common knowledge that it has had no impact at all on research or policy planning to speak of and it has now been abolished. ... Storage and retrieval of information in the Ministry is, therefore, still primitive and it has not been unknown for ministry officials to seek the assistance of foreign embassies in Colombo in the preparation of their briefs" (Kodikara, 1982: p. 10).

In 1986, Dr. Kodikara was appointed as the first Professor of International Relations at the University of Colombo, which marks the genesis of formal academic field of International Relations in the university system in Sri Lanka. However, two years prior to the appointment of Dr. Kodikara at the University of Colombo, a Memorandum of Understanding (MoU) was signed between the university and the School of International Service (SIS) of the American University in Washington D.C. in August 1984 to develop a collaborative program within the broader field of public and international affairs. As a result, a two - year Master's Degree program in International Relations was established in 1985, the only one of its kind in Sri Lanka. Thus, the University of Colombo pioneered in teaching International Relations with the inception of the Master's Degree in 1985, and the appointment of Dr. Kodikara as the first Professor of International Relations in 1986.

3.2 The establishment of the Department of International Relations at the University of Colombo

Establishing the Department of International Relations has been a long process. In addition to the pioneering work of Professor Kodikara, it is a collaborative effort of several other scholars in the university, such as Professor Amal Jayawardena, Professor George Cooray and Professor Nayani Melegoda. Initially, some modules in International Relations were offered to the undergraduates by the Department of History and Political Science, and later this was developed as an independent Special Degree Programme. The first batch of students who followed the special degree programme in International Relations was graduated in 2000. However, the 
The Evolution of International Relations Scholarship and its Praxis in Sri 105 Lanka: A Review of Historical Evidence

establishment of the Department of International Relations is marked on 29th July 2010, by the Extraordinary Gazette Notification (1658/36) of 17 June 2010 under the leadership of Professor Nayani Melegoda. ${ }^{2}$

Within the current public university system in Sri Lanka, University of Colombo is the only university granting a Special (four years) and General Degree (three years) in International Relations. Subsequently, several other universities (such as the University of Kelaniya and also the Eastern University of Sri Lanka) started similar undergraduate course modules, but the degrees are granted as Bachelor of Arts in International Studies (University Grants Commission-Sri Lanka, 2019: p.256). University of Colombo offers several post graduate degrees in International Relations, namely Master of Arts in International Relations and MPhil/PhD in International Relations. Table 1 summarizes the enrolment of students in various IR courses offered by the University of Colombo since 2014.

Table 1. Student enrolment in various IR courses at University of Colombo

\begin{tabular}{|r|r|r|r|r|r|r|}
\hline Year & $\begin{array}{c}\text { Total Number } \\
\text { of } \\
\text { Undergraduate } \\
\text { Students in } \\
\text { Faculty of Arts }\end{array}$ & $\begin{array}{c}\text { Number } \\
\text { of First } \\
\text { Year IR } \\
\text { Students }\end{array}$ & $\begin{array}{c}\text { Number of } \\
\text { Special } \\
\text { Degree IR } \\
\text { Students }\end{array}$ & $\begin{array}{c}\text { Number of } \\
\text { Students in } \\
\text { IR } \\
\text { Certificate } \\
\text { Course }\end{array}$ & $\begin{array}{c}\text { Intake of } \\
\text { Master's } \\
\text { Degree IR } \\
\text { Students }\end{array}$ & $\begin{array}{c}\text { Total } \\
\text { number of } \\
\text { Mphil/PhD } \\
\text { IR Students }\end{array}$ \\
\hline 2018 & 2144 & 191 & 36 & N/A & 30 & 24 \\
\hline 2017 & 2150 & 161 & 42 & 30 & 46 & 7 \\
\hline 2016 & 2445 & 190 & 28 & 58 & 45 & 7 \\
\hline 2015 & 2584 & 206 & 39 & 55 & 26 & 5 \\
\hline 2014 & 2493 & 185 & N/A & 51 & 39 & 5 \\
\hline
\end{tabular}

Source: Compiled by the authors based on University of Colombo Annual Reports 2014, 2015, 2016, 2017, 2018 and data received from Information and Documentation Center of the Faculty of Arts, University of Colombo.

\footnotetext{
${ }^{2}$ Information is based on authors' own experiences and observations.
} 
3.3. Contemporary International Relations teaching in Sri Lanka: An overview

What is the contemporary academic understanding of International Relations in Sri Lanka? The best possible method to answer this question is based on what is taught currently at the university level and also what has been specialized by the International Relations scholars in the country.

Figure 1. Subfields of IR taught at public universities in Sri Lanka

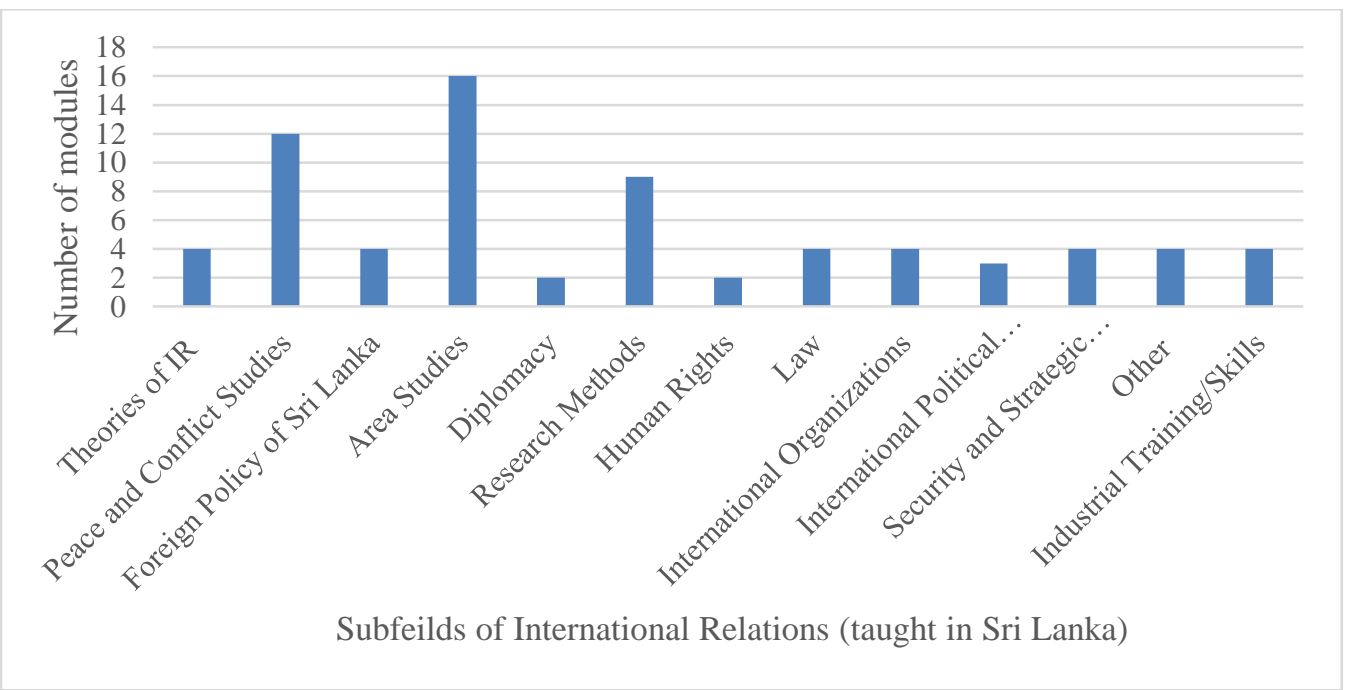

Note: Author drawn. The illustration is based on the absolute number of undergraduate course modules taught at the Department of International Relations, University of Colombo and Department of International Studies, University of Kelaniya. When categorizing, the authors considered the keywords in the title of each module and in some cases the aims and scope of the module. However, the authors admit that there could be minor overlaps between certain course modules. The section 'Other' consists of various multidisciplinary course modules such as Environmental Governance or Migration Studies.

As visualized in Figure 1, there is an increasing tendency of teaching Area Studies and Peace and Conflict Studies modules. However, over the years graduates who followed IR special degree (at University of Colombo) have done research dissertations focusing on a diverse array of subjects including International and Regional Organizations, critiques of work done by UN and 
its agencies, Sustainable Development Goals, Human Rights and Human Security, to name a few. Many have studied success stories of regional cooperation (i.e. European Integration and ASEAN) and challenges of regional cooperation in the South Asian region. Testing of theories of IR in country case studies, foreign policy analysis, Area Studies of which India, Japan and the United Kingdom are popular topics. Geopolitics, Bi-lateral and Multilateral relations are also studied. The USA and China are favourite topics of the students. Hard Power and in recent times Soft Power case studies are also taken up by these undergraduate students. Conflict Resolution case studies, and Peace Studies are also frequently selected areas. Sri Lanka Foreign Policy and its bilateral relations with various selected countries are also a most favoured choice. ${ }^{3}$ In addition to the above academic focus, many of the IR undergraduates receive the opportunity to complete their 'industrial training' module at the Ministry of Foreign Relations, and various other international and non-governmental organizations including Think Tanks in Sri Lanka.

\section{The Ministry of Foreign Relations and its contribution to IR in Sri}

\section{Lanka}

The growth of the academic discipline of IR cannot be traced independent of the Ministry of Foreign Relations Sri Lanka. As discussed above, the ministry represents the 'praxis' of Sri Lanka's foreign policy and has substantially underpinned the growth of the academic discipline of IR. Below, the present study examines several contributions of the Ministry of Foreign Relations that directly and indirectly advances the academic discipline of IR.

\subsection{Establishing a research division in the Ministry of Foreign Relations}

When tracing the historical growth of the Ministry of Foreign Relations, it is noticeable that at the very inception, there was no ministerial division focusing on research relating to the praxis (see Figure 2, 3, 4 and 5). In 1982, Kodikara also notes the necessity of research-based foreign policy praxis, by stating that "[a]lthough a policy planning division has existed for some time in the Ministry, it is common knowledge that it has had no impact at all on research or policy planning to speak of and it has now been

\footnotetext{
${ }^{3}$ The list has been compiled based on authors' own observations.
} 
abolished....Storage and retrieval of information in the Ministry is still primitive..." (Kodikara, 1982: p. 10).

Figure 2. Ministry of Defence and External Affairs in 1955

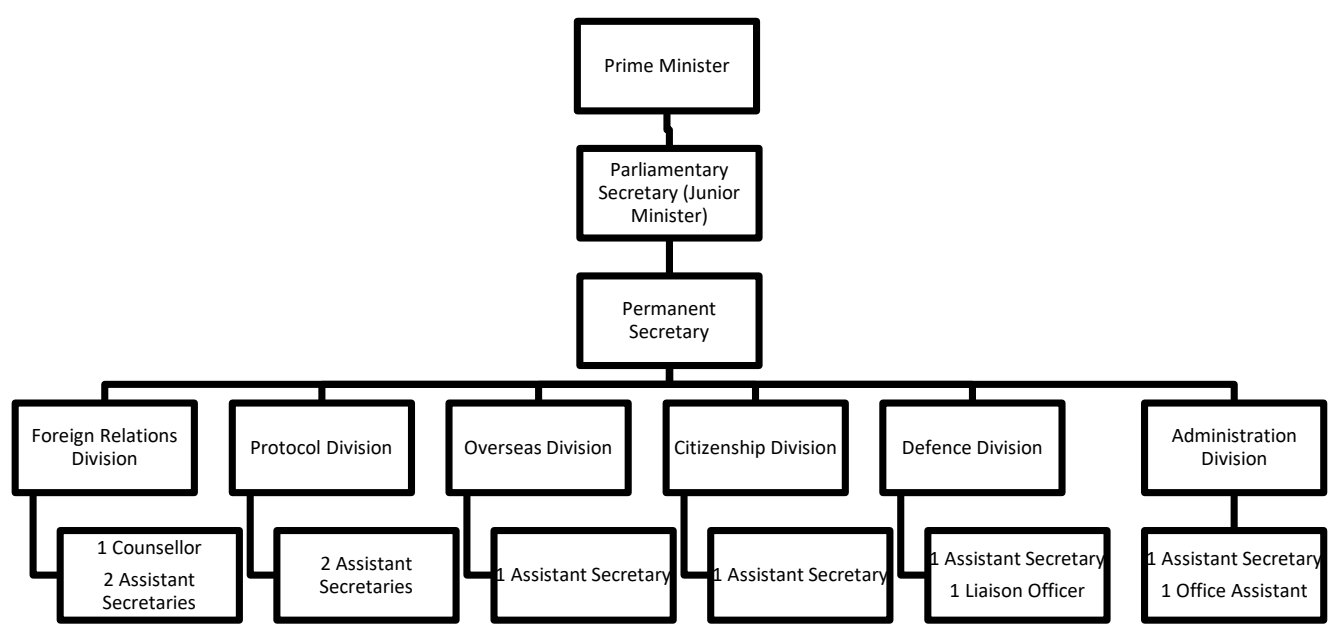

Source: Nissanka, 1984.

Figure 3: Foreign Office of Sri Lanka in 1970

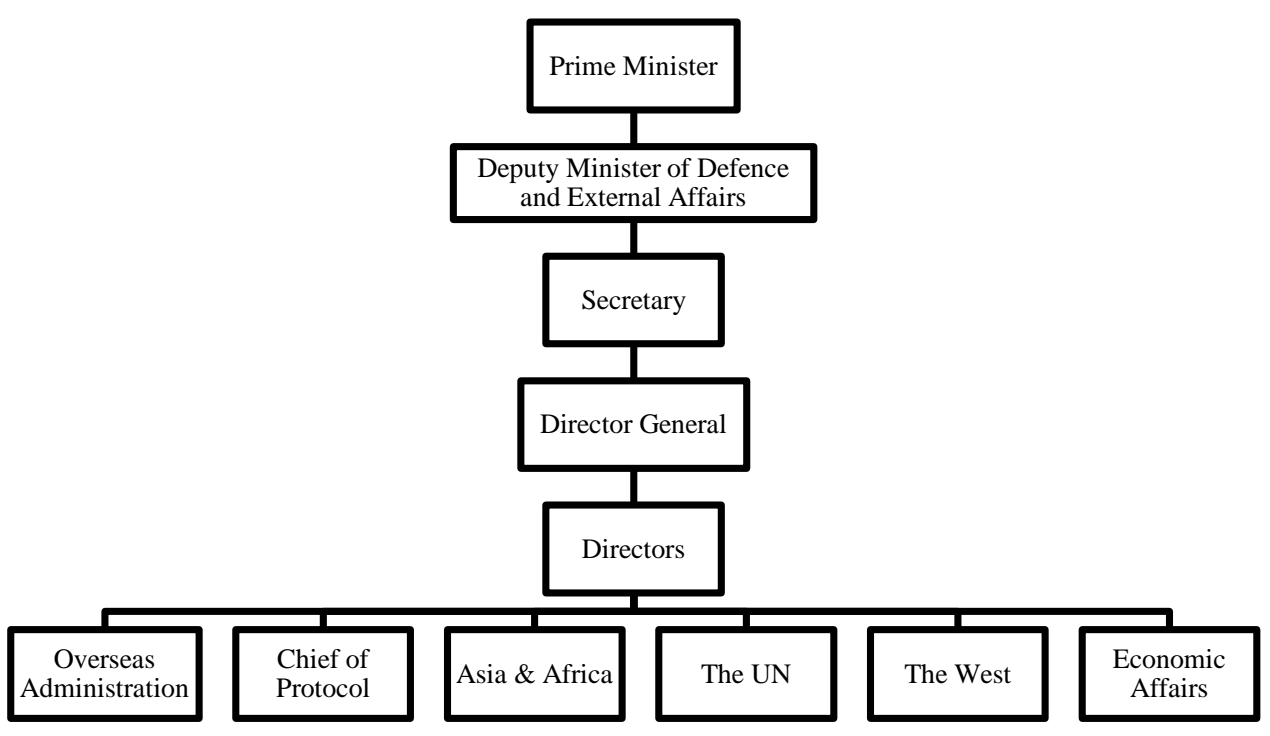

Source: Nissanka, 1984. 
Figure 4: Department of Foreign Affairs in 1974

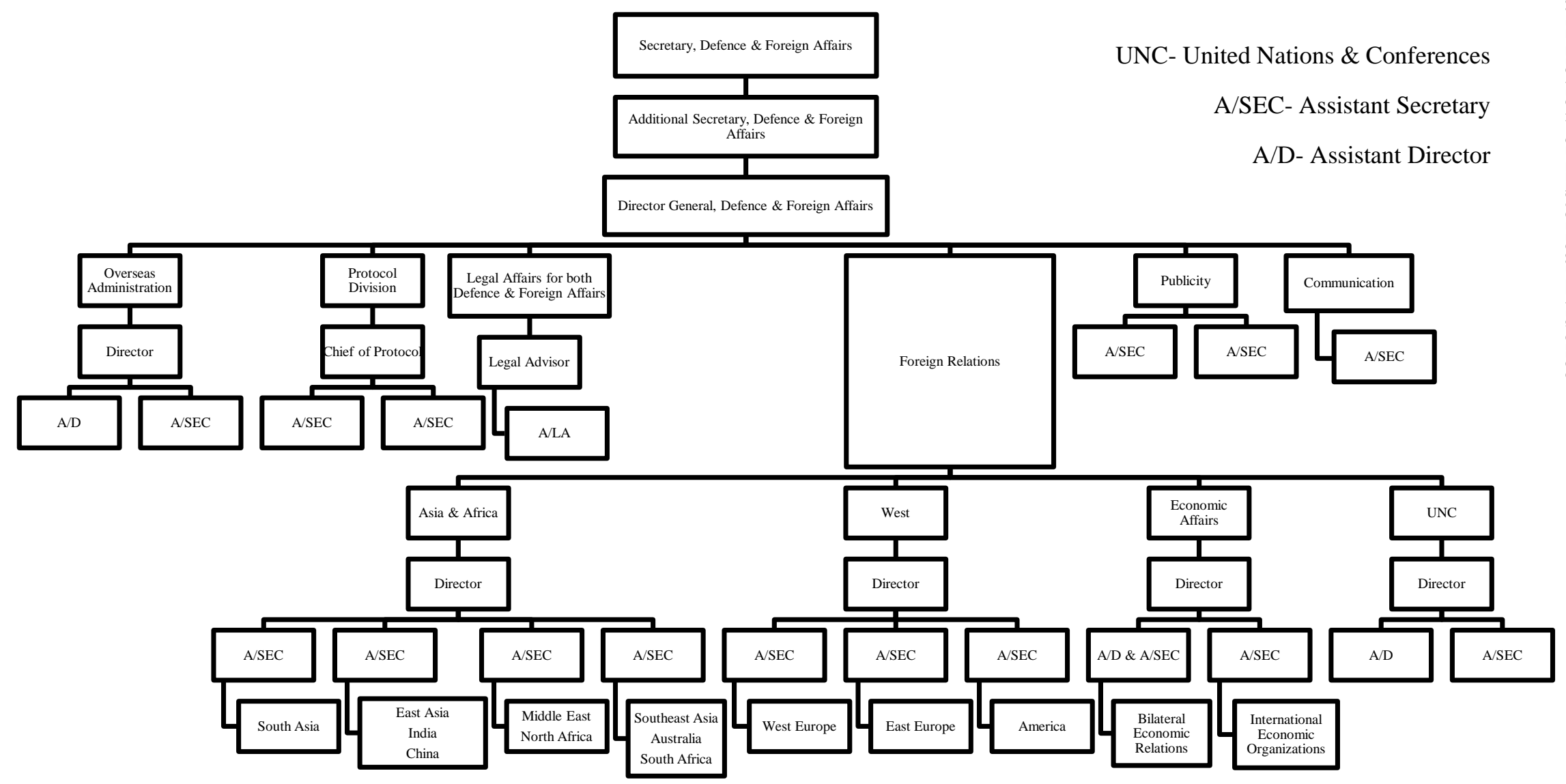

Source: Nissanka, 1984. 


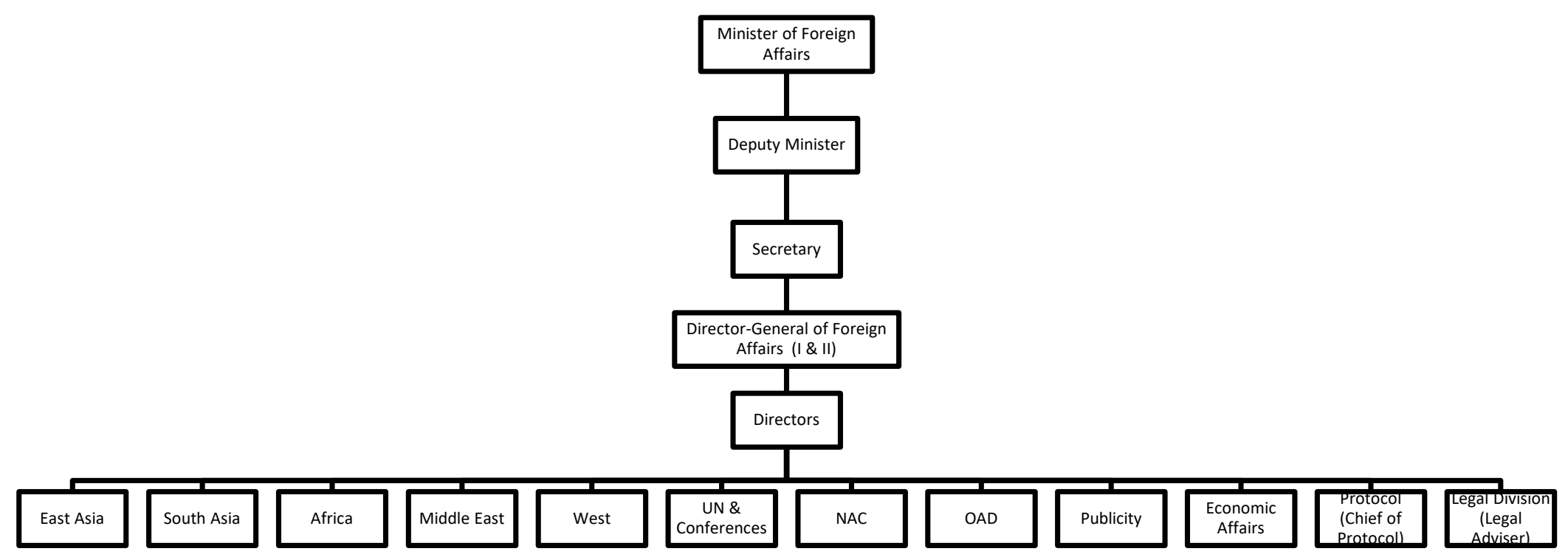

$\mathrm{NAC}=$ Non-Aligned Conf. Division

OAD- Overseas Administration Division

Protocol Division is under Chief of Protocol

Deputy Directors

Assistant Directors

Source: Kodikara,1982, p. 9. 
Filling this void, in 2019, the Ministry of Foreign Relations (then Ministry of Foreign Affairs) established a Policy Planning, Research and Human Development Division (see Figure 6), understanding the prevailing vacuum of research-based foreign policy formation and decision making in the current practice. "The objective of establishing this division is to undertake research, provide analyses on issues of contemporary global relevance, develop policy briefs on specific aspects of Sri Lanka's foreign policy and undertake assessments of existing policies which would contribute to the long-term strategic planning of the Foreign Ministry. In the short to medium term, the Policy Planning and Research Division will also work towards formulating a Foreign Policy White Paper. This is expected to be an allencompassing policy statement with an actionable timeframe. It would involve all key stakeholders in foreign policy coming together and formulating a cohesive action plan that would deliver the optimum returns to the people of Sri Lanka in the international sphere" (MFR, 2020c). 


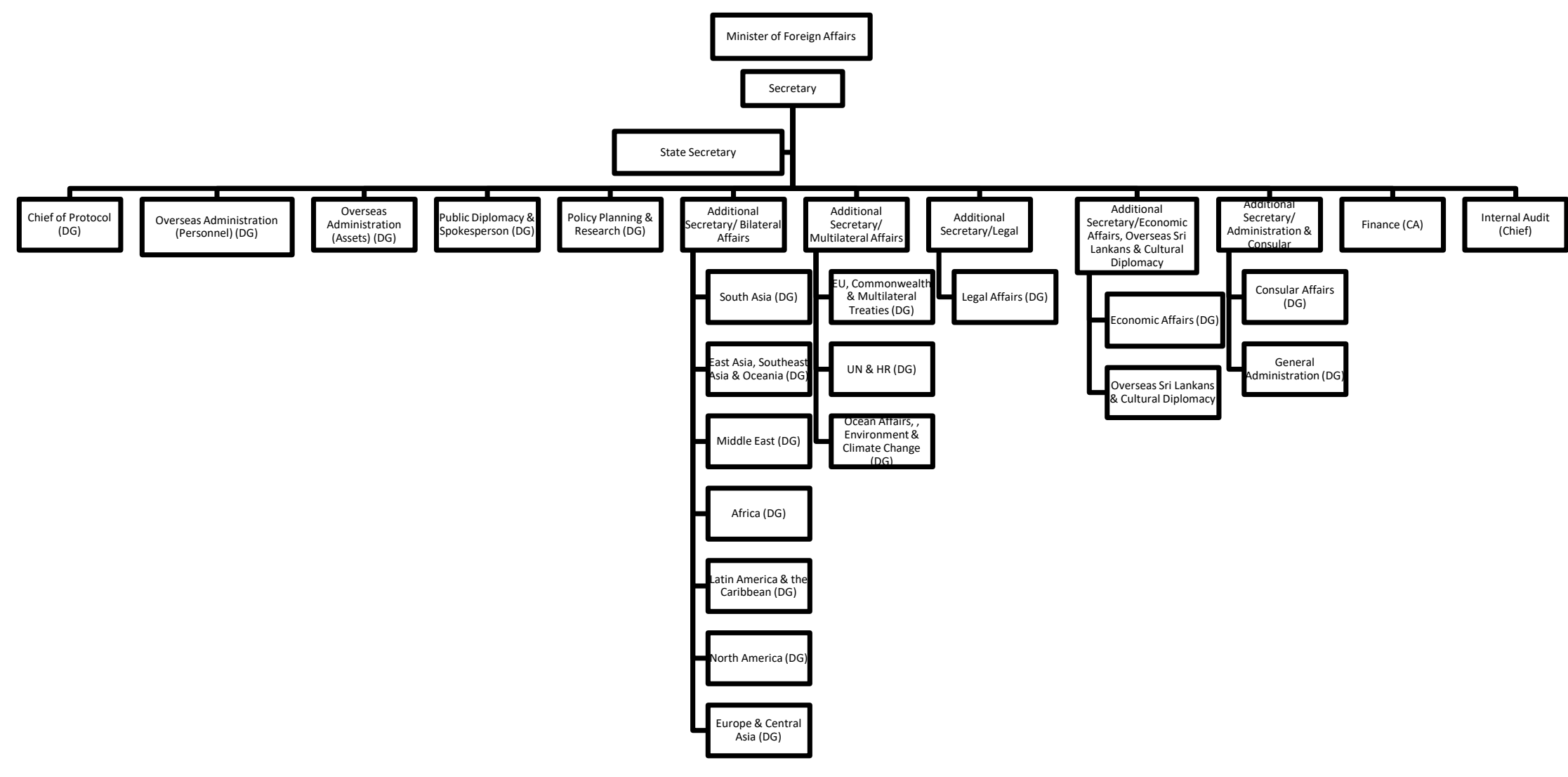


Establishing a Policy Planning and Research Division within the ministerial preview is an imperative measure for the advancement of the discipline and its praxis. On one hand, there is a greater opportunity to liaise with other academic institutions in the island for better policy formulation, and, on the other hand, this will also open opportunities to address the issue of lack of expertise in the foreign policy praxis that Jennings identified in 1954.

4.2 Late Lakshman Kadirgamar and the 'Journal of International Relations in a Globalising World'

As the most widely remembered and remarkably successful Foreign Minister of Sri Lanka (Roberts, 2012: p. 4), Lakshman Kadirgamar's contribution to the growth of the academic discipline of IR in Sri Lanka is worth revisiting. During turbulent times (with the ongoing civil war in the country during 1994-2001 and 2004-2005) his contributions to the advancement of the 'National Brand' abroad as the then Minister of Foreign Affairs was noteworthy. His vision of Sri Lanka's foreign policy and its position in the international system is unique and futuristic. "As foreign minister he was deeply concerned with advancing a well-thought-out view of that series of complex and often contradictory processes that constitute the international relations of our times. ...He also made strenuous efforts to develop Sri Lankan expertise in international relations. He took steps to ensure that recruits for Sri Lanka's diplomatic service were chosen purely on merit, and he improved their training. His stint as Foreign Minister is considered a golden era, in which a previously disparate and ineffective group of diplomats was given punch and purpose..." (Roberts, 2012: p. 6).

Recognizing the necessity of developing the depth of Sri Lanka's expertise in world politics, Kadirgamar launched the Journal International Relations in a Globalising World, of which he was the editor-in-chief. "He indicated that the discipline of international relations had expanded to such levels that any conceivable topic had bearing on it. He said the journal was his dream and he decided to take plunge into the deep end when some had raised doubts...." (Roberts, 2012: p. 6). With a tragic irony, the journal was launched on $12^{\text {th }}$ August 2005, a few hours before his assassination. Only two issues of the journal were produced, the second dated July-December 2005, has been largely prepared before Kadirgamar's death. The journal was published by Bandaranaike Center for International Studies as a Sage Publication (Roberts, 2012: p. 237n7). 


\section{Establishment of other research institutes/think tanks in IR}

In addition to the academic establishments within the public university system in Sri Lanka, several research institutes and Think Tanks have been established during the last fifty years advancing both praxis and research in the field of IR. The Bandaranaike Centre for International Studies, the Lakshman Kadirgamar Institute for International Relations and Strategic Studies, Bandaranaike International Diplomatic Training Institute, and Regional Center for Strategic Studies are the prevailing non-degree offering, research, cooperate and service-oriented bodies in the field of IR in Sri Lanka.

\subsection{The Bandaranaike Centre for International Studies}

The Bandaranaike Centre for International Studies (BCIS) is the academic wing of the S. W. R. D. Bandaranaike National Memorial Foundation established by the Act of Parliament No. 2 of 1975, in memory of the late Prime Minister Mr. S. W. R. D. Bandaranaike. The centre was inaugurated modestly on 9th December 1974 in a section of the Bandaranaike Memorial International Conference Hall complex, where the historic Fifth Conference of Heads of States and Government of the Non Aligned Nations was held in August 1976 (History, Bandaranaike Centre for International Studies, 2020). From its inception, BCIS was chaired by the late Sirmavo Bandaranaike, the world's first woman Prime Minister, until her demise in October 2000.

The Centre is non-profit and service-oriented organization and can be considered as both teaching and a research institute geared towards graduate teaching, research and advanced study of International Relations with particular emphasis on South and South East Asia and the Third World (History, Bandaranaike Centre for International Studies, 2020). As Mrs. Bandaranaike herself stated at the inaugural address of the seminar on 'IndoSri Lankan Relations' in 1990, the aims and objects of BCIS are "to promote an understanding and belief among our people in the development of friendly relations among all nations, to advance the cause of peace and security, and to instruct students in international relations and to disseminate information on world problems and issues to as wide an audience as possible" (Bandaranaike, 1991:p. 3). It offers several non-degree level postgraduate courses in International Relations, Human Rights and Transitional Justice. The late Hon. Lakshman Kadirgamar, P.C., M.P., Minister of Foreign 
Affairs, chaired the BCIS from $01^{\text {st }}$ August 2002 until his assassination by terrorists on $12^{\text {th }}$ August 2005.

5.2 The Lakshman Kadirgamar Institute of International Relations and Strategic Studies

The Lakshman Kadirgamar Institute of International Relations and Strategic Studies (LKI) is currently affiliated with the Ministry of Foreign Relations of Sri Lanka. LKI was first established as 'Sri Lanka Institute of Strategic Studies' by the Parliamentary Act No. 45 of 2000 (Sri Lanka Institute of Strategic Studies Act 2000). The functions of the institute are highly research oriented as specified in its inception. Conducting research and studies on broader defence and national security, international relations, and related socio, political and economic issues, providing necessary information and data for relevant authorities for strategic planning, to promote research by and liaise between governmental and non-governmental bodies, exchanging information and promoting discussions on the above matters are some of the major tasks of the institute.

In the backdrop of the assassination of Hon. Lakshman Kadirgamar (former Minister of Foreign Affairs during 1994 - 2001 and 2004 - 2005) (MFR, 2020e) the institute was renamed as 'The Lakshman Kadirgamar Institute of International Relations and Strategic Studies,' by the Parliamentary Act No. 32 of 2006 (Sri Lanka Institute of Strategic Studies Amendment Act 2006). With the amendment, the institute's scope was also broadened as a multidisciplinary research institute, dedicated to study strategic interests of Sri Lanka including defense, national security, law, economics, cultural relations, agriculture, environment, peace, post-conflict issues and the study of Sri Lanka's international relations (Sri Lanka Institute of Strategic Studies Amendment Act 2006). Currently LKI is the premier Foreign Policy think tank in the country.

\subsection{Bandaranaike International Diplomatic Training Institute}

Bandaranaike International Diplomatic Training Institute (BIDTI) is also affiliated to the Ministry of Foreign Relations. While LKI is more research oriented, BIDTI serves as the official training institute of Ministry of Foreign Relations. Established in 1995 under the guidance of late Prime Minister Sirmavo Bandaranaike, BIDTI aims at advancing the skills of Sri Lanka's Foreign Service. The institute offers training to the general public, yet it mostly serves the training requirements of the Ministry of Foreign Relations. 
As noted by late Prime Minister Sirmavo Bandaranaike at the inaugural address of the institute in 1995, "[t] which I wish to highlight. Firstly, it is intended to provide a training to recruits to the professional Foreign Service as well as other functionaries of the Ministry who are engaged in the conduct of foreign relations. Such a system of training should have been initiated decades ago considering that we embarked on our career as an independent sovereign state 47 years ago, but with the launching of this institute, we should be able, I hope, to create a truly professional service with the necessary attributes, skills and commitment"(BIDTI 2020). Broadening the scope of the institute, in 2019, BIDTI launched a journal, Diplomacy and World Affairs, providing an academic forum for practitioners and scholars in IR Sri Lanka.

\section{Conclusion}

The academic discipline of International Relations has evolved nearly thirty years in Sri Lanka after formally introducing it to the University of Colombo in 1986. The early praxis (in the immediate aftermath of the independence) of Sri Lanka's international relations has notably been without the academic expertise. However, after thirsty years, the practitioner of Sri Lanka's international relations, that is the Ministry of Foreign Relations, is now better equipped with several training and research institutes attached to it. A few IR related journals have been launched in Sri Lanka though some of them are no longer functioning. There are a few International Relations academic symposia at the university and think tank level providing opportunities for young and emerging IR scholars and practitioners to present their research and experiences. Many of the IR undergraduates complete their 'industrial training' module at the Ministry of Foreign Relations indicating various possibilities of bridging the academic vs. practitioner's gap in the field. For a better praxis of Sri Lanka's international relations and foreign policy decision making, further collaborations between the Ministry of Foreign Relations and the university system is necessary. Such collaborations will not only benefit the practitioners, but also the academia and, in the long run, the entire populace in Sri Lanka. 
The Evolution of International Relations Scholarship and its Praxis in Sri 117 Lanka: A Review of Historical Evidence

\section{References}

Bain, William. (2019). Continuity and change in international relations 19192019. International Relations, 33(2), 132-141. https:/doi.org/ 10.1177/0047117819850238.

Bandaranaike. Sirimavo. (1991). Inaugural Address. In S. U. Kodikara (Ed.), Dilemmas of Indo-Sri Lanka Relations (p.3). Colombo: Bandaranaike Centre for International Relations.

BCIS. (2020, February). Bandaranaike Centre for International Studies History. http://bcis.edu.lk/en/history/.

Booth, Ken. (2019). International Relations: The Story So Far. International Relations, 33(2), 358-390. htps://doi.org/1026 $\underline{1.1177 /} \underline{7117819851}$

Jayasundara, N. S. (2014). Higher Education Policy in Sri Lanka: Implementation in state Universities. Scientific Research Journal (SCIRJ), 2(2), pp. 41- 44.

Jayawardane, Amal. "Security Studies in Sri Lanka: A Late Development" Sri Lanka Journal of International law Vol 13 (2001)

Jennings, Ivor. (1954). Politics in Ceylon since 1952. Pacific Affairs, 27(4), pp.338-352.

Kalugalagedera, T. P. and Kaushalya, T. (2017). History of University Education in Sri Lanka: A Literature Review. Colombo: Centre for Poverty Analysis. http://www.cepa.lk/content_images/publications/ documents/english-20180508102118.pdf.

Kodikara, S.U. (1982). Foreign Policy of Sri Lanka: A Third World Perspective. Delhi: Chanakya Publications. 
Mendis, V. (2018, June). Brief Overview of Sri Lanka's Foreign Relations to Post-Independence.https://www.mfa.gov.lk/brief-overview-ofsri-lankas-foreign-relations-to-post-independence/.

Mendis, V. L. B. (1983). Foreign Relations of Sri Lanka: From Earliest Times to 1965. Colombo: Thisara Prakashakayo.

MFR. (2020a, May). Ministry of Foreign Affairs - Overview [Online]. https:// www.mfa.gov.lk/the-ministry/.

MFR. (2020b, May). Ministry of Foreign Affairs - Milestones. https:// www.mfa.gov.lk/the-ministry/milestones/.

MFR. (2020c, May). Policy Planning, Research and Human Resources Development. https://www.mfa.gov.lk/division/policy-planningresearch-2/policy-planning-research/.

MFR. (2020d, May). Organizational Structure. https://www.mfa.gov.lk/theministry/organisational-structure/.

MFR. (2020e, May). Ministry of Foreign Affairs - Former Foreign Ministers. https://www.mfa.gov.lk/former-foreign-ministers/.

Nissanka, H.S.S. (1984). Sri Lanka's Foreign Policy: A Study of Non Alignment. Ghaziabad: Vikas Publishing.

Phadnis, U. (1967). Review: S. U. Kodikara. Indo-Ceylon Relations since Independence. Colombo, Ceylon Institute of World Affairs, 1965. International Studies 9(2), 223-224. https://doi.org/10.1177/00208 $\underline{8176700900207 .}$

Roberts, A. (2012). Dare the deepening tide: Lakshman Kadirgamar on the revolutionary of our times. In Sir Adam Roberts (Ed.), Democracy, Sovereignty and Terror (pp. 3-36), London: I.B.Tauris 
The Evolution of International Relations Scholarship and its Praxis in Sri 119 Lanka: A Review of Historical Evidence

Scott, Andrew. (2006, May). Sir Ivor Jennings - Peradeniya's first vicechancellor. Daily News Online. http://archives.dailynews.lk/2006/ $\underline{05 / 02 / \text { fea04.asp. }}$

Sri Lanka Institute of Strategic Studies Act, No. 45 of 2000.

Sri Lanka Institute of Strategic Studies Amendment Act, No. 32 of 2006.

Thistlethwaite, F. (1967). Report on the Establishment of the University of Colombo. Sessional Paper XXVI.

University Grants Commission-Sri Lanka. (2019). Admissions Handbook 2019/20. Colombo: University Grants Commission Sri Lanka. https://www.ugc.ac.lk/en/university-admissions/admissionhandbook-201920.html.

Wriggins, Howard. (1960). Ceylon: Dilemmas of a New Nation. New Jersey: Princeton University Press. 